\title{
Synthesis and Characterization of High-Efficiency Red Phosphorescent Iridium(III) Complexes with 1-(4-(Trifluoromethyl)phenyl)isoquinoline Ligand
}

\author{
Zheng Zhao, ${ }^{1}$ Xiao-Han Yang, ${ }^{1}$ Zi-Wen Tao, ${ }^{1}$ Han-Ru Xu, ${ }^{1}$ Kai Liu, ${ }^{1}$ \\ Guang-Ying Chen, ${ }^{2}$ Zheng-Rong Mo, ${ }^{2}$ Shui-Xing Wu, ${ }^{1}$ Zhi-Gang Niu, ${ }^{1,2}$ \\ and Gao-Nan $\mathrm{Li}^{1 \text {,* }}$ \\ ${ }^{1}$ Key Laboratory of Electrochemical Energy Storage and Energy Conversion of Hainan Province, \\ College of Chemistry and Chemical Engineering, Hainan Normal University, Haikou 571158, China \\ ${ }^{2}$ Key Laboratory of Tropical Medicinal Plant Chemistry of Ministry of Education, Hainan Normal University, \\ Haikou 571158, China \\ *Corresponding author: E-mail: ligaonan2008@163.com (G.-N. Li)
}

Received: 05-05-2019

\begin{abstract}
Two new tfmpiq-based bis-cyclometalated iridium(III) complexes, [(tfmpiq) $\left.)_{2} \operatorname{Ir}(\mathrm{imdzppo})\right]$ (2a) and [(tfmpiq) 2 Ir(idzpo)] (2b) (where tfmpiq $=1$-(4-(trifluoromethyl)phenyl)isoquinoline, imdzppo $=2$-(imidazo[1,2-a]pyridin-2-yl)phenol, idzpo $=2$ - $(2 H$-indazol-2-yl $)$ phenol $)$, have been synthesized and fully characterized. The single crystal structure of $\mathbf{2 b}$ has been determined. The relationship between the structures and photophysical properties of both complexes are considered, and the DFT calculations have been used to further support the deduction. These Ir(III) complexes emit red light with quantum yields of 39.9-51.9\% in degassed $\mathrm{CH}_{2} \mathrm{Cl}_{2}$ solution at room temperature. Also, their emission originates from a hybrid ${ }^{3} \mathrm{MLCT} /{ }^{3} \mathrm{LLCT} /{ }^{3} \mathrm{LC}$ excited state. All these results show that iridium(III) complexes $\mathbf{2} \mathbf{a}-\mathbf{2} \mathbf{b}$ are suitable for red-phosphorescent materials in OLEDs.
\end{abstract}

Keywords: Iridium(III) complex; 1-(4-(Trifluoromethyl)phenyl)isoquinoline; Red phosphorescence; DFT calculation

\section{Introduction}

Organic light-emitting diodes (OLEDs) have attracted great attention on the development of modern optoelectronic technologies such as full-color displays and solid-state lighting sources. ${ }^{1-3}$ Particularly, cyclometalated iridium(III) complexes $\left(\left[\operatorname{Ir}\left(\mathrm{C}^{\wedge} \mathrm{N}\right)_{3}\right]\right.$ or $\left.\left[\left(\mathrm{C}^{\wedge} \mathrm{N}\right)_{2} \operatorname{Ir}(\mathrm{LX})\right]\right)$ are the most valuable emitting materials in the fabrication of OLEDs, owing to their relatively short excited-state lifetime, high phosphorescence efficiency and excellent color-tuning capability. ${ }^{4,5}$ As compared to other colors, red electrophosphorescent emitting phosphors are difficult to maintain high device efficiency, since their quantum efficiencies tend to decrease as the emission wavelength increases in accordance with the energy gap law. ${ }^{6-8}$ Thus, the design and syntheses of highly efficient red-emitting iridium complexes remain a challenge.
1-Phenylisoquinoline (piq) is one typical ligand framework to construct red iridium complexes. A large number of piq-based Ir(III) complexes have been reported during the past decade..$^{9-13}$ Among these examples, iridium complexes of fluorinated phenylisoquinoline show strong electroluminescence brightness and efficiency. This is because the fluorine groups could not only modify the electronic properties but also decrease the rate of nonradioactive deactivation and improve phosphorescence quantum yields. ${ }^{14}$ Therefore, in 2006, K.-H. Fang and co-workers first reported $\operatorname{Ir}(\mathrm{tfmpiq})_{2}$ acac $(\mathrm{acac}=$ acetylacetonate) complex, which emitted red phosphorescence with a wavelength maximum at $631 \mathrm{~nm}$, and the quantum yield was up to $31 \%{ }^{15}$ Subsequently, in 2014 , S. Zhang et al. developed red $\operatorname{Ir}(\mathrm{tfmpiq})_{2}$ tpip complex (tpip = tetraphenylimidodiphosphinate), which achieved emission at $622 \mathrm{~nm}$ with quantum efficiency of $15 \% .{ }^{16}$ In the same 
year, we employed 2,2-bipyridine as the ancillary ligand to synthesize $\operatorname{Ir}(\text { tfmpiq) })_{2}$ bipy complex, which exhibited a maximum emission peak at $594 \mathrm{~nm}$ with quantum yield of $14 \% .{ }^{17}$ Recently, in 2016, S. Aoki group reported tris-cyclometalated iridium complex, $\operatorname{Ir}(\mathrm{tfpiq})_{3}$, which displayed red phosphorescence at $600 \mathrm{~nm}$ with quantum yield of $25 \%{ }^{18}$

However, these conventional ancillary ligands used in tfmpiq-based iridium (III) complexes didn't show significantly red-shift with high quantum efficiencies. Thus, we wanted to attempt other types of ancillary ligands for $\operatorname{Ir}(\text { tfmpiq })_{2}(\mathrm{LX})$ complexes, aiming to increase quantum efficiencies and further reduce the energy gap to reach to longer wavelength region. Our group previously reported four btp-based deep-red phosphorescent iridium(III) complexes with different ancillary ligands. ${ }^{19}$ Among them, the $\operatorname{Ir}(\mathrm{III})$ complex with the picolinic acid as ancillary ligand could achieve a more red-shift relative to ones with $\mathrm{N}^{\wedge} \mathrm{N}$ ancillary ligands. The $\mathrm{N}^{\wedge} \mathrm{O}$-type ancillary ligand containing $-\mathrm{OH}$ group could dramatically raise the highest occupied molecular orbital (HOMO) level and lead to a narrow HOMO-LUMO energy gap. Unfortunately, the quantum yield is very low (12\%), as results of the fluorine-free main ligands in $\left[\operatorname{Ir}(\mathrm{btq})_{2} \mathrm{pic}\right]$ complex.

Herein, we chose fluorinated 1-phenylisoquinoline (tfmpiq) as the cyclometalated ligand and $\mathrm{N}^{\wedge} \mathrm{O}$-type ligand (imdzppo/idzpo) as the ancillary ligand to synthesize two iridium(III) complexes (Scheme 1). Their photophysical and electrochemical properties are investigated, and the lowest-energy electronic transitions and the lowest-lying triplet excited state are calculated with density functional theory (DFT) and time-dependent DFT (TDDFT).

\section{Experimental}

\section{1. Materials and Instrumentations}

$\mathrm{IrCl}_{3} \cdot 3 \mathrm{H}_{2} \mathrm{O}$ was purchased from Energy Chemical and all reagents were used without further purification unless otherwise stated. All solvents were dried using standard procedures. Solvents used for electrochemistry and spectroscopy were spectroscopic grade. The target ligands, 1-(4-(trifluoromethyl)phenyl)isoquinoline $(\mathbf{1}){ }^{20}{ }^{2}$-(imidazo[1,2-a]pyridin-2-yl)phenol (a) ${ }^{21}$ and 2-(2H-indazol-2 $-\mathrm{yl})$ phenol $(\mathbf{b})^{22}$ were prepared according to the literature procedures.

${ }^{1} \mathrm{H}$ NMR spectra were recorded on a Bruker AM 400 $\mathrm{MHz}$ instrument. Chemical shifts were reported in ppm relative to $\mathrm{Me}_{4} \mathrm{Si}$ as internal standard. MALDI-TOF-MS spectra were recorded on a Bruker Autoflex ${ }^{\mathrm{II}}$ TM TOF/ TOF instrument. Elemental analyses were performed on a Vario EL Cube Analyzer system. UV-vis spectra were recorded on a Hitachi U3900/3900H spectrophotometer. Fluorescence spectra were carried out on a Hitachi F-7000 spectrophotometer in deaerated $\mathrm{CH}_{2} \mathrm{Cl}_{2}$ solutions at $298 \mathrm{~K}$ and $77 \mathrm{~K}$.

Cyclic voltammetry (CV) was performed on a CHI 1210B electrochemical workstation, with a glassy carbon electrode as the working electrode, a platinum wire as the counter electrode, an $\mathrm{Ag} / \mathrm{Ag}^{+}$electrode as the reference electrode, and $0.1 \mathrm{M} \mathrm{n}-\mathrm{Bu}_{4} \mathrm{NClO}_{4}$ as the supporting electrolyte.

\section{2. Synthesis of (tfmpiq) ${ }_{2} \operatorname{Ir}(\mathrm{imdzppo})$ (2a)}

A mixture of $\mathrm{IrCl}_{3} \cdot 3 \mathrm{H}_{2} \mathrm{O}(295 \mathrm{mg}, 0.84 \mathrm{mmol})$ and the 1-(4-(trifluoromethyl)phenyl)isoquinoline $(500 \mathrm{mg}$,
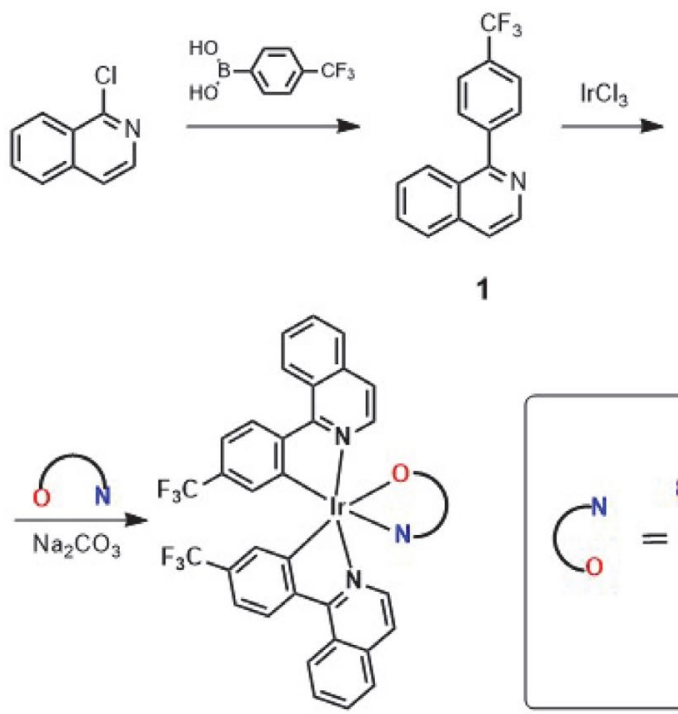

$2 a \sim 2 b$

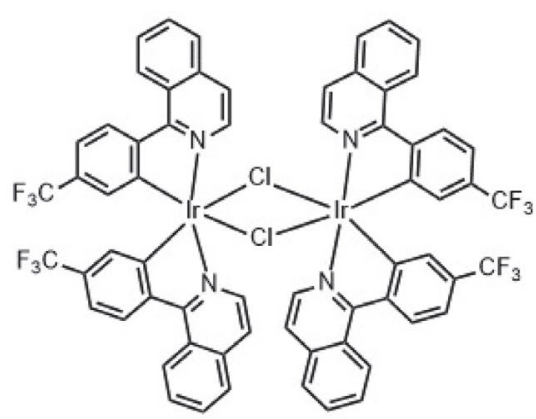

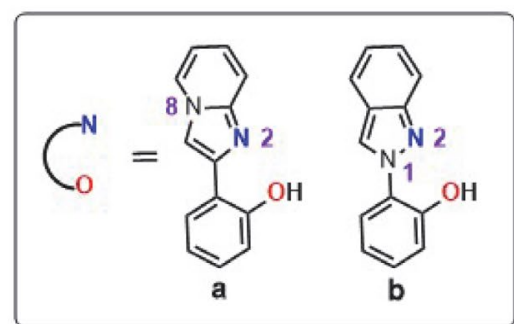

Scheme 1. Synthetic routes of $\operatorname{Ir}(\mathrm{III})$ complexes $\mathbf{2 a - 2 b}$. 
$1.82 \mathrm{mmol}$ ) in $15 \mathrm{~mL}$ of 2-ethoxyethanol and $\mathrm{H}_{2} \mathrm{O}$ (v:v = 2:1) was heated at $120{ }^{\circ} \mathrm{C}$ under nitrogen for 12 hours. Upon cooling to room temperature, the orange-red precipitate was collected by filtration and washed with cooled ether and $\mathrm{MeOH}$. After drying, the crude product of chloro-bridged dimer complex $\left[(\operatorname{tfmpiq})_{2} \operatorname{Ir}(\mu-\mathrm{Cl})\right]_{2}$ was used directly in next step without further purification. Then a slurry of the crude chloro-bridged dimer $(100 \mathrm{mg}$, $0.065 \mathrm{mmol}$ ), 2-(imidazo[1,2-a]pyridin-2-yl)phenol (35 $\mathrm{mg}, 0.16 \mathrm{mmol}$ ) and $\mathrm{Na}_{2} \mathrm{CO}_{3}(55 \mathrm{mg}, 0.52 \mathrm{mmol})$ in 2-ethoxyethanol $(10 \mathrm{~mL})$ was heated at $120^{\circ} \mathrm{C}$ under nitrogen for 10 hours. After the solvent was removed, the mixture was poured into water and extracted with $\mathrm{CH}_{2} \mathrm{Cl}_{2}$ three times, and then evaporated. The residue was purified by flash column chromatography (petroleum ether : dichloromethane $=5: 1 \sim 1: 1)$ to afford the iridium complex 2a as a red solid (55 mg, yield: $45 \%) .{ }^{1} \mathrm{H}$ NMR $(400 \mathrm{MHz}$, $\left.\mathrm{CDCl}_{3}\right) \delta(\mathrm{ppm}) 8.95(\mathrm{~d}, J=8.0 \mathrm{~Hz}, 1 \mathrm{H}), 8.92(\mathrm{~d}, J=6.4$ $\mathrm{Hz}, 1 \mathrm{H}), 8.78(\mathrm{~d}, J=4.8 \mathrm{~Hz}, 2 \mathrm{H}), 8.29(\mathrm{~s}, 1 \mathrm{H}), 8.24(\mathrm{~d}, J=$ $8.0 \mathrm{~Hz}, 1 \mathrm{H}), 7.81-7.92(\mathrm{~m}, 10 \mathrm{H}), 7.71-7.75(\mathrm{~m}, 3 \mathrm{H}), 7.38-$ $7.40(\mathrm{~m}, 2 \mathrm{H}), 7.18(\mathrm{~d}, J=4.8 \mathrm{~Hz}, 2 \mathrm{H}), 7.08-7.10(\mathrm{~m}, 2 \mathrm{H})$, $6.61(\mathrm{~d}, J=6.4 \mathrm{~Hz}, 1 \mathrm{H}), 6.21(\mathrm{~s}, 1 \mathrm{H})$. MALDI-TOF calcd for $\mathrm{C}_{45} \mathrm{H}_{27} \mathrm{~F}_{6} \mathrm{IrN}_{4} \mathrm{O}$ : $946.172\left([\mathrm{M}+\mathrm{H}]^{+}\right)$. Found: 946.504 . Anal. Calcd. for $\mathrm{C}_{45} \mathrm{H}_{27} \mathrm{~F}_{6} \mathrm{IrN}_{4} \mathrm{O}$ : C 57.14, H 2.88, N 5.92. Found: C 57.10, H 2.97, N 5.89.

\section{3. Synthesis of (tfmpiq) ${ }_{2} \operatorname{Ir}(\mathrm{idzpo})(2 \mathrm{~b})$}

Complex $2 \mathbf{b}$ ( $52 \mathrm{mg}$, yield: $46 \%$ ) was obtained by the method similar to the preparation of $2 \mathbf{a}$ using 2 - $(2 \mathrm{H}$-indazol-2-yl)phenol instead of 2-(imidazo[1,2-a]pyridin-2-yl) phenol. ${ }^{1} \mathrm{H}$ NMR $\left(400 \mathrm{MHz}, \mathrm{CDCl}_{3}\right) \delta(\mathrm{ppm}) 9.01(\mathrm{~d}, \mathrm{~J}=$ $8.4 \mathrm{~Hz}, 1 \mathrm{H}), 8.87(\mathrm{~d}, J=6.4 \mathrm{~Hz}, 1 \mathrm{H}), 8.84(\mathrm{~d}, J=8.4 \mathrm{~Hz}$, $1 \mathrm{H}), 8.49-8.51(\mathrm{~m}, 2 \mathrm{H}), 8.25(\mathrm{~d}, J=6.4 \mathrm{~Hz}, 1 \mathrm{H}), 8.18(\mathrm{~d}, J$ $=8.4 \mathrm{~Hz}, 1 \mathrm{H}), 7.87-8.89(\mathrm{~m}, 1 \mathrm{H}), 7.67-7.83(\mathrm{~m}, 5 \mathrm{H}), 7.61$ $(\mathrm{d}, J=8.4 \mathrm{~Hz}, 1 \mathrm{H}), 7.35(\mathrm{~d}, J=6.4 \mathrm{~Hz}, 1 \mathrm{H}), 7.30(\mathrm{dd}, J=1.6$ $\mathrm{Hz}, 8.4 \mathrm{~Hz}, 1 \mathrm{H}), 7.13-7.15$ (m, 2H), 7.04-7.09 (m, 2H), 6.85-6.88 (m, 1H), 6.69-6.73 (m, 1H), 6.44-6.48 (m, $1 \mathrm{H})$, 6.32-6.36 (m, 1H), 6.16-6.21 (m, 2H). MALDI-TOF calcd for $\mathrm{C}_{45} \mathrm{H}_{27} \mathrm{~F}_{6} \mathrm{IrN}_{4} \mathrm{O}: 946.172\left([\mathrm{M}+\mathrm{H}]^{+}\right)$. Found: 946.386 . Anal. Calcd. for $\mathrm{C}_{45} \mathrm{H}_{27} \mathrm{~F}_{6} \mathrm{IrN}_{4} \mathrm{O}$ : C 57.14, H 2.88, N 5.92. Found: C 56.97, H 2.81, N 5.99.

\section{4. Crystallographic Studies}

X-ray diffraction data were collected with an Agilent Technologies Gemini A Ultra diffractometer equipped with graphite-monochromated Mo-Ka radiation $(\lambda=$ $0.7107 \AA$ ) at room temperature. Data collection and reduction were processed with CrysAlisPro software. ${ }^{23}$ The structure was solved and refined using full-matrix leastsquares based on $F^{2}$ with program SHELXS-97 and SHELXL- $97^{24}$ within Olex $2 .{ }^{25}$ Crystallographic data (excluding structure factors) for the structural analysis have been deposited with the Cambridge Crystallographic Data Center as supplementary publication No. CCDC
1836887 (2b). Copies of the data can be obtained free of charge via www.ccdc.ac.uk/conts/retrieving.html (or from The Director, CCDC, 12 Union Road, Cambridge CB2 1EZ, UK, Fax: +44-1223-336-033. E-mail: deposit@ ccdc.cam.ac.uk.).

\section{5. Computational Method}

All calculations were carried out with Gaussian 09 software package. ${ }^{26}$ The density functional theory (DFT) and time-dependent DFT (TD-DFT) were employed with no symmetry constraints to investigate the optimized geometries and electron configurations with the Becke three-parameter Lee-Yang-Parr (B3LYP) hybrid density functional theory. ${ }^{27-29}$ The LANL2DZ basis set was used for the iridium(III), whereas the $6-31 G^{*}$ basis set was adopted for the ligands. Solvent effects were considered within the SCRF (self-consistent reaction field) theory using the polarized continuum model (PCM) approach to model the interaction with the solvent. ${ }^{30,31}$

\section{Results and Discussion}

\section{1. Synthesis and Characterization}

Scheme 1 outlines the synthetic routes for iridium complexes $\mathbf{2 a - 2 b}$ investigated in this work. The main ligand, 1-(4-(trifluoromethyl)phenyl)isoquinoline (tfmpiq), was prepared from the synthesis of 1-chloroisoquinoline and (4-(trifluoromethyl)phenyl)boronic acid according to the literature procedure. ${ }^{20}$ The two constitutional isomer ligands, 2-(imidazo[1,2-a]pyridin-2-yl)phenol (imdzppo) and 2-(2H-indazol-2-yl)phenol (idzpo), were formed by an Ortoleva-King reaction and a $\mathrm{PII} / \mathrm{P}^{\mathrm{V}}=\mathrm{O}$ redox cycling reaction, respectively. ${ }^{21,22}$ Complexes $\mathbf{2 a}-\mathbf{2} \mathbf{b}$ were obtained in moderate yields from the above ligands by a conventional two-step reaction. In the first step, a chloro-bridged dimer was formed by the reaction of iridium trichloride hydrate with an excess of main ligand. Then this dimmer was cleaved via treatment with ancillary ligand in the presence of $\mathrm{Na}_{2} \mathrm{CO}_{3}$ to produce the heteroleptic iridium complex. The two complexes were structurally characterized by ${ }^{1} \mathrm{H}$ NMR spectroscopy, mass spectrometry and elemental analysis.

\section{2. Structural Description}

The crystal of $\mathbf{2 b}$ was obtained by slow evaporation of $\mathrm{CH}_{2} \mathrm{Cl}_{2} / \mathrm{MeOH}$ solution and the structure was determined through X-ray diffraction analysis (Fig. 1a). The crystallographic data and structure refinement details are listed in Table 1; selected bond lengths and bond angles are collected in Table 2.

As shown in Fig. 1a, the Ir(III) adopts a distorted octahedral geometry with the $\mathrm{C}^{\wedge} \mathrm{N}$ ligands in cis-C, $\mathrm{C}^{\prime}$ and trans- $\mathrm{N}, \mathrm{N}^{\prime}$ configurations. The average distance of Ir-C 

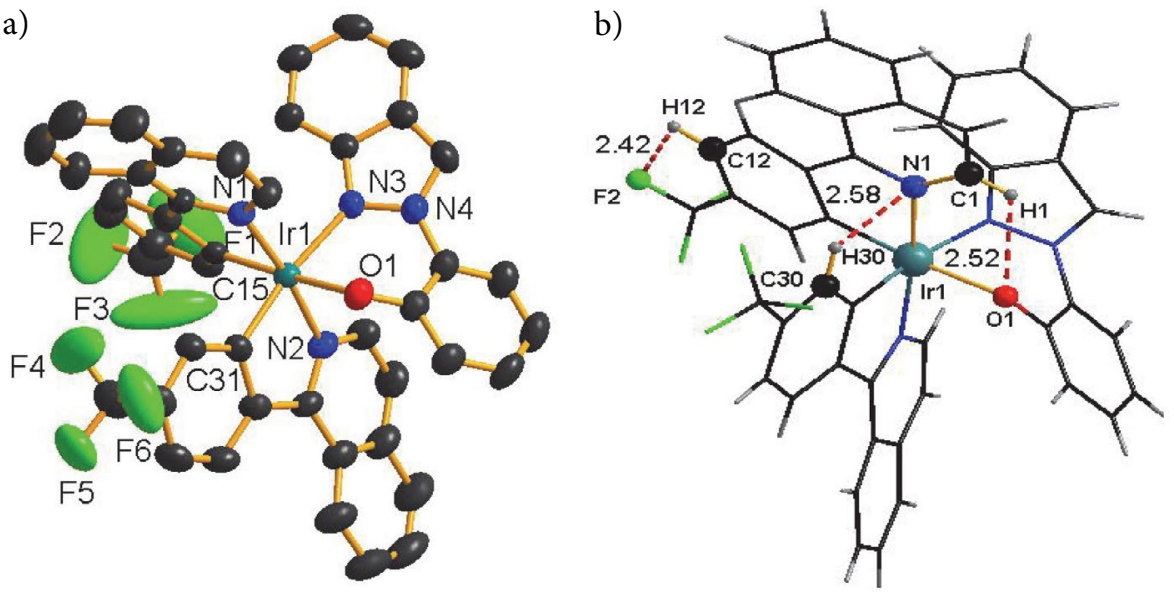

Fig. 1. (a) ORTEP view of $\mathbf{2 b}$ with the atom-numbering scheme at the $50 \%$ probability level. Hydrogen atoms and solvent molecules are omitted for clarity. (b) Selected non-covalent contacts of the $\mathrm{C}-\mathrm{H} \cdots \mathrm{O}, \mathrm{C}-\mathrm{H} \cdots \mathrm{F}$ and $\mathrm{C}-\mathrm{H} \cdots \mathrm{N}$ types (dashed red lines). Atoms involved in hydrogen bonds are shown as balls of arbitrary radii. All other atoms and covalent bonds are represented as wires or sticks.

bonds $\left(\operatorname{Ir}-\mathrm{C}_{\mathrm{av}}=1.989 \AA\right)$ is shorter than that of the $\operatorname{Ir}-\mathrm{N}$ bonds ( $\mathrm{Ir}-\mathrm{N}_{\mathrm{av}}=2.082 \AA$ ), as reported in other iridium(III) complexes. ${ }^{32,33}$ Notably, bonds between iridium and the $\mathrm{N}^{\wedge} \mathrm{O}$ ligand $(\mathrm{Ir}-\mathrm{N} 3=2.156 \AA$, $\mathrm{Ir}-\mathrm{O} 1=2.153 \AA$ ) are longer than those between iridium and the $\mathrm{C}^{\wedge} \mathrm{N}$ ligands ( $\mathrm{Ir}-\mathrm{C} 15$ $=1.985 \AA, \mathrm{Ir}-\mathrm{C} 31=1.993 \AA, \mathrm{Ir}-\mathrm{N} 1=2.040 \AA, \mathrm{Ir}-\mathrm{N} 2=$ $2.051 \AA$ ), resulting from strong trans influence of the carbon donors. ${ }^{34}$ The angles of atoms on the para positions of the octahedron range from $171.61(18)^{\circ}$ to $172.59(17)^{\circ}$, which are close to straight lines. For comparison, the two $\mathrm{C}-\mathrm{Ir}-\mathrm{N}$ bite angles of the $\mathrm{C}^{\wedge} \mathrm{N}$ ligand are $79.23^{\circ}$ and $79.47^{\circ}$, while the $\mathrm{N}-\mathrm{Ir}-\mathrm{O}$ bite angle of the ancillary ligand is $82.78^{\circ}$. This may be due to the rigid effect of the five-membered ring at the metal center. ${ }^{35}$ In addition, the hydrogen-bonding interactions in the crystal structure are

Table 1. Crystallographic data for complex $\mathbf{2 b} \cdot \mathrm{H}_{2} \mathrm{O}$.

\begin{tabular}{ll}
\hline Empirical formula & $\mathrm{C}_{45} \mathrm{H}_{29} \mathrm{~F}_{6} \mathrm{IrN}_{4} \mathrm{O}_{2}$ \\
$\mathrm{M}_{\mathrm{r}}(\mathrm{g} / \mathrm{mol})$ & 963.92 \\
Crystal system & Monoclinic \\
Space group & $P 2_{1} / c$ \\
$a(\AA)$ & $12.5501(5)$ \\
$b(\AA)$ & $18.1261(7)$ \\
$c(\AA)$ & $16.6857(5)$ \\
$\alpha\left(^{\circ}\right)$ & 90 \\
$\beta\left(^{\circ}\right)$ & $95.252(3)$ \\
$\gamma\left({ }^{\circ}\right)$ & 90 \\
$V\left(\AA^{3}\right)$ & $3779.8(2)$ \\
$Z$ & 4 \\
$D_{\text {calcd }}\left(\mathrm{Mg} / \mathrm{m}^{3}\right)$ & 1.694 \\
$F(000)$ & 1896 \\
$\mathrm{Absorption}$ coefficient $\left(\mathrm{mm}^{-1}\right)$ & 3.607 \\
$R_{\text {int }}$ & 0.0354 \\
$\mathrm{GOF}\left(F^{2}\right)$ & 1.026 \\
$R_{1}^{\mathrm{a}}, w R_{2}^{\mathrm{b}}(\mathrm{I}>2 \sigma(\mathrm{I}))$ & $0.0378,0.0796$ \\
$R_{1}^{\mathrm{a}}, w R_{2}^{\mathrm{b}}($ all data $)$ & $0.0592,0.0909$ \\
\hline${ }^{a} R_{1}=\Sigma|| F_{\mathrm{o}}|-| F_{\mathrm{c}}|| \Sigma\left|F_{\mathrm{o}}\right| \cdot{ }^{b} w R_{2}=\left[\Sigma w\left(F_{\mathrm{o}}{ }^{2}-F_{\mathrm{c}}{ }^{2}\right)^{2} / \Sigma w\left(F_{\mathrm{o}}{ }^{2}\right)\right]^{1 / 2}$
\end{tabular}

Table 2. Selected bond distances $(\AA)$ and angles $\left(^{\circ}\right)$ for complex $\mathbf{2 b}$. $\mathrm{H}_{2} \mathrm{O}$.

\begin{tabular}{cccc}
\hline Ir1-N1 & $2.040(4)$ & Ir1-N3 & $2.156(4)$ \\
Ir1-O1 & $2.153(4)$ & Ir1-C31 & $1.993(5)$ \\
Ir1-N2 & $2.051(4)$ & Ir1-C15 & $1.985(5)$ \\
N1-Ir1-O1 & $93.51(15)$ & C31-Ir1-N2 & $79.47(19)$ \\
N1-Ir1-N2 & $172.47(17)$ & C31-Ir1-N3 & $171.61(18)$ \\
O1-Ir1-N3 & $82.78(15)$ & C15-Ir1-O1 & $172.59(17)$ \\
C31-Ir1-O1 & $90.02(17)$ & C15-Ir1-N3 & $98.77(17)$ \\
C15-Ir1-N1 & $79.23(19)$ & C15-Ir1-C31 & $88.93(19)$ \\
\hline
\end{tabular}

Table 3. Hydrogen bonding arrangements for complex $\mathbf{2 b} \cdot \mathrm{H}_{2} \mathrm{O}\left(\AA{ }^{\circ}{ }^{\circ}\right)$.

\begin{tabular}{lcccc}
\hline \multicolumn{1}{c}{$D-\mathbf{H} \cdots A$} & $D-\mathbf{H}$ & $\mathbf{H} \cdots A$ & $D \cdots A$ & $D-\mathbf{H} \cdots A$ \\
\hline $\mathrm{C} 1-\mathrm{H} 1 \cdots \mathrm{O} 1$ & 0.93 & 2.52 & $3.075(6)$ & 118 \\
$\mathrm{C} 12-\mathrm{H} 12 \cdots \mathrm{F} 2$ & 0.93 & 2.42 & $2.732(1)$ & 100 \\
$\mathrm{C} 30-\mathrm{H} 30 \cdots \mathrm{N} 1$ & 0.93 & 2.58 & $3.091(6)$ & 115 \\
\hline
\end{tabular}

presented in Fig. $1 \mathrm{~b}$ and the details are summarized in Table 3. From Fig. 1b, the three selected non-covalent contacts of the $\mathrm{C}-\mathrm{H} \cdots \mathrm{O}, \mathrm{C}-\mathrm{H} \cdots \mathrm{F}$ and $\mathrm{C}-\mathrm{H} \cdots \mathrm{N}$ types are attributed to intramolecular hydrogen bonds, making three five-membered rings, respectively.

\section{3. Electronic Absorption Spectra}

The UV-vis absorption spectra of complexes $\mathbf{2 a - 2 b}$ measured in $\mathrm{CH}_{2} \mathrm{Cl}_{2}$ solution at room temperature are depicted in Fig. 2, and the data are provided in Table 4. The absorption spectra reveal strong absorption bands below $400 \mathrm{~nm}$, which are assigned to intraligand $\pi-\pi^{*}$ transitions centered on the $\mathrm{C}^{\wedge} \mathrm{N}$ main ligand and the $\mathrm{N}^{\wedge} \mathrm{O}$ ancillary ligand. The weak absorption bands extending from $400 \mathrm{~nm}$ to $550 \mathrm{~nm}$ are attributed to the metal to ligand ${ }^{1} \mathrm{MLCT} /{ }^{3} \mathrm{MLCT}$ transitions. ${ }^{36-38}$ In comparison 
Table 4. Photophysical and electrochemical data of $\mathbf{2 a - 2 b}$.

\begin{tabular}{cccccccc}
\hline Complex & $\begin{array}{c}\text { Absorption }^{a} \\
\lambda_{\text {abs }}(\mathbf{n m})\end{array}$ & $\lambda_{e m}^{298 K}(\mathbf{n m})^{a}$ & $\lambda_{e m}^{7 m^{K}}(\mathbf{n m})^{b}$ & $\begin{array}{c}\Phi_{\text {em }}{ }^{c} \\
(\mathbf{\%})\end{array}$ & $\begin{array}{c}E_{o x}{ }^{a} \\
(\mathbf{V})\end{array}$ & $\begin{array}{c}\mathbf{H O M O}^{d} \\
(\mathbf{e V})\end{array}$ & $\begin{array}{c}\mathbf{H O M O}^{e} \\
(\mathbf{e V})\end{array}$ \\
\hline 2a & $237,293,360,399,464$ & $618,662(\mathrm{sh})$ & $621,666(\mathrm{sh})$ & 39.9 & 0.87 & -5.67 & -4.91 \\
2b & $234,288,342,397,477$ & $628,670(\mathrm{sh})$ & $630,680(\mathrm{sh})$ & 51.9 & 1.05 & -5.85 & -5.20 \\
\hline
\end{tabular}

${ }^{a}$ Data were collected from degassed $\mathrm{CH}_{2} \mathrm{Cl}_{2}$ solutions at $298 \mathrm{~K}$. ${ }^{b}$ Data were collected from degassed $\mathrm{CH}_{2} \mathrm{Cl}_{2}$ solutions at 77

K. ${ }^{c} f a c-\operatorname{Ir}(\text { ppy })_{3}$ as referenced standard (0.4) ${ }^{41}{ }^{d} \mathrm{HOMO}$ energies are deduced from the equation $\mathrm{HOMO}=-\left(E_{\mathrm{ox}}+4.8 \mathrm{eV}\right)$.

${ }^{e}$ Obtained from theoretical calculations.

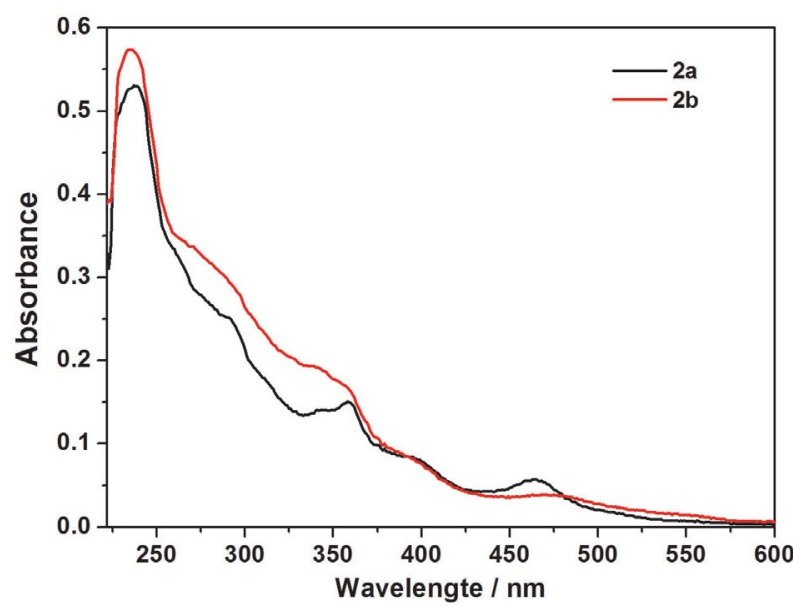

Fig. 2. Electronic absorption spectra of $\mathbf{2 a}-\mathbf{2} \mathbf{b}$ in $\mathrm{CH}_{2} \mathrm{Cl}_{2}$ at room temperature.

with $\mathbf{2 a}$, the lowest lying absorption band for complex $\mathbf{2 b}$ is slightly red-shifted, presumably depending on the different $\mathrm{N}$-heterocycle ancillary ligands. This assumption will be proved by electrochemistry analyses and DFT calculations.

\section{4. Emission Properties}

Photoluminescence (PL) emission spectra of complexes $\mathbf{2 a - 2 b}$ in degassed $\mathrm{CH}_{2} \mathrm{Cl}_{2}$ solution at $298 \mathrm{~K}$ and 77 $\mathrm{K}$ are displayed in Fig. 3 and the corresponding data are also summarized in Table 4 . In both cases, the emission spectra show the broad emission maxima at $618-628 \mathrm{~nm}$ together with a shoulder peak at $662-670 \mathrm{~nm}$, which makes them red emitters. For their emission, the excited states are attributed to a mixing of ${ }^{3} \mathrm{MLCT}$ and ${ }^{3} \mathrm{LC}$ state. ${ }^{39,40}$ As seen, the emission band of $\mathbf{2 b}$ is also red-shifted relative to $\mathbf{2 a}$, in good agreement with absorption analyses. When the temperature is decreased to $77 \mathrm{~K}$, the emission maxima of $2 \mathbf{a}-$ $\mathbf{2 b}$ are a slightly bathochromic shift compared to the $298 \mathrm{~K}$ spectra, as reported in our earlier literature. ${ }^{13}$ Clearly, these complexes exhibit vibronic bands at $77 \mathrm{~K}$, which again demonstrate that their emission states are hybrid states with ${ }^{3} \mathrm{MLCT}$ and ${ }^{3} \mathrm{LC}$ characters.

Phosphorescence relative quantum yields $\left(\Phi_{\mathrm{em}}\right)$ of $\mathbf{2 a}$ and $\mathbf{2 b}$ in dichloromethane solution at room temperature were measured to be 39.9 and $51.9 \%$ (Table 4) respectively,
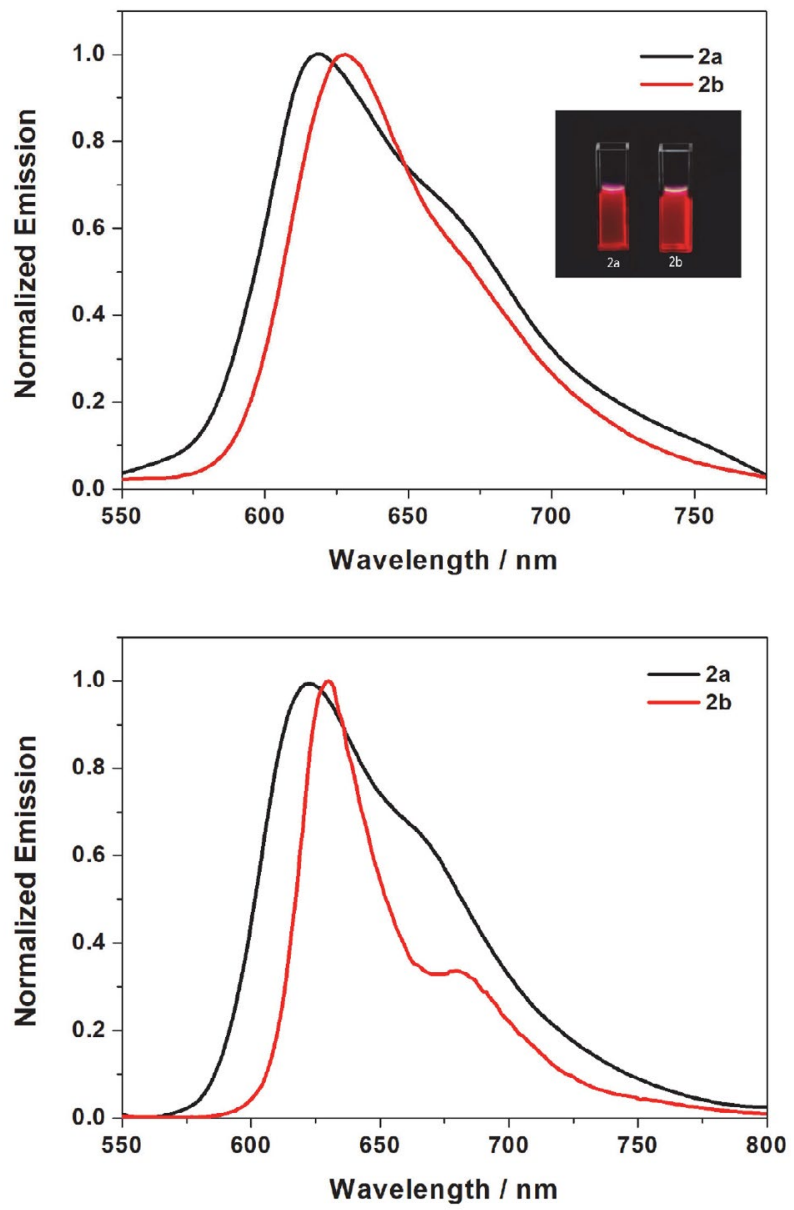

Fig. 3. Normalized emission spectra of $\mathbf{2 a}-\mathbf{2} \mathbf{b}$ in degassed $\mathrm{CH}_{2} \mathrm{Cl}_{2}$ solution at $298 \mathrm{~K}$ (left) and $77 \mathrm{~K}$ (right).

using typical phosphorescent $f a c-\operatorname{Ir}(\text { ppy })_{3}$ as a standard $\left(\Phi_{\text {em }}=0.40\right) .{ }^{41}$ As expected, complexes $\mathbf{2 a - 2 b}$ have relatively high quantum yields, due to the effect of fluorinated backbones. ${ }^{42,43}$ Specially, the quantum efficiency of $\mathbf{2 b}$ is larger than that of $\mathbf{2} \mathbf{a}$. The results manifest nitrogen atoms at 1,2-positions are more effective than 2,8-positions.

\section{5. Theoretical Calculations}

Density functional theory (DFT) and time-dependent DFT (TDDFT) calculations have been performed for complexes $\mathbf{2 a - 2 b}$ to gain insights into the lowest-energy 
electronic transitions. The most representative molecular frontier orbital diagrams for these complexes are presented in Fig. 4. The calculated spin-allowed electronic transitions are provided in Table 5, as well as compared with the experimental absorption spectra data. The electron density distributions are summarized in Table S1.

As shown in Fig. 4, the HOMOs of these complexes are mainly localized on the metal center and the phenyl ring of ancillary ligands, whereas the LUMOs are primarily dominated on the whole $\mathrm{C}^{\wedge} \mathrm{N}$ ligands. Besides, the HOMO-1 of complex $\mathbf{2 a}$ is located on iridium ion, the cyclometalated ligands and a little part of the ancillary ligands. The theory calculations of DFT reveal that the lowest-energy spin-allowed transitions of $\mathbf{2} \mathbf{a}-\mathbf{2} \mathbf{b}$ are derived from $\mathrm{HOMO} / \mathrm{HOMO}-1 \rightarrow \mathrm{LUMO}$ and $\mathrm{HOMO} \rightarrow \mathrm{LUMO}$ transitions (Table 5), consequently assigned to metal-to-ligand charge transfer transitions and ligand-to-ligand $\pi-\pi^{*}$ transitions. These calculations support the photophysical properties discussed above.

To gain the origins of emission for complexes $\mathbf{2 a}-\mathbf{2} \mathbf{b}$, we also employed the DFT calculations to investigate the triplet excited-state characters. The results of the TD-DFT calculations for the triplet states are listed in Table 6. For both the studied complexes, the two lowest lying triplet states $\left(\mathrm{T}_{1}\right.$ and $\left.\mathrm{T}_{2}\right)$ are predominantly from $\mathrm{HOMO} \rightarrow \mathrm{LU}-$ $\mathrm{MO}, \mathrm{HOMO}-1 \rightarrow \mathrm{LUMO}, \mathrm{HOMO} \rightarrow \mathrm{LUMO}+1, \mathrm{HO}-$ $\mathrm{MO}-1 \rightarrow \mathrm{LUMO}+1$ HOMO $-2 \rightarrow$ LUMO and HOMO $-3 \rightarrow \mathrm{LU}-$ MO transitions. According to electron density distributions in Table S1, the HOMOs are mainly localized at the ancillary ligands, while LUMOs/LUMO+1s at the $\mathrm{C}^{\wedge} \mathrm{N}$ ligands. The HOMO-1s/HOMO-2s/HOMO-3s are composed of Ir $d$-orbital, $\mathrm{C}^{\wedge} \mathrm{N}$ ligands and ancillary ligands. Thereby, both of the two lowest-lying triplet states $\left(\mathrm{T}_{1}\right.$ and $\mathrm{T}_{2}$ ) have a mixed ${ }^{3} \mathrm{MLCT} /{ }^{3} \mathrm{LLCT} /{ }^{3} \mathrm{LC}$ character for the two

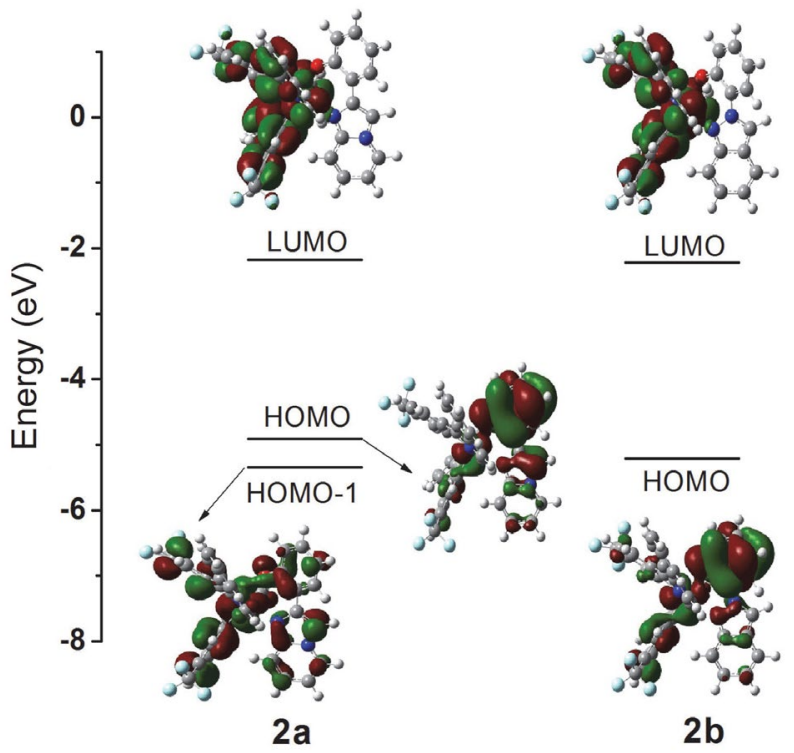

Fig. 4. The frontier molecular orbital diagrams of complexes $\mathbf{2 a - 2 b}$ from DFT calculations.

complexes, except $\mathrm{T}_{2}$ of $\mathbf{2 a}$ with limited ${ }^{3} \mathrm{MLCT}$ contribution. The lowest-lying triplet states of $\mathbf{2 a}$ have similar transition paths with those of $\mathbf{2} \mathbf{b}$, indicating that the different positions of $\mathrm{N}$ atoms on ancillary ligands have no obvious effect on emissive behavior.

\section{6. Electrochemical Properties}

The electrochemical behaviors of both iridium complexes were investigated by cyclic voltammetry and the electrochemical waves are shown in Fig. 5. The respective electrochemical data and estimated HOMO energy levels are also reported in Table 4 . Complexes $\mathbf{2 a - 2} \mathbf{b}$ exhibit a

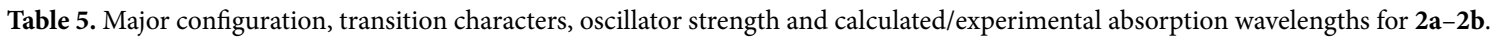

\begin{tabular}{|c|c|c|c|c|c|c|c|}
\hline Complex & & Major Configuration & Transition & Character & $\begin{array}{l}\text { Oscillation } \\
\text { Strength }\end{array}$ & $\begin{array}{l}\text { Calcd } \\
(\mathrm{nm})\end{array}$ & $\begin{array}{l}\text { Exptl } \\
(\mathrm{nm})\end{array}$ \\
\hline \multirow[t]{2}{*}{$2 \mathbf{a}$} & $\mathrm{S}_{1}$ & HOMO $\rightarrow$ LUMO (93\%) & LLCT & $\pi_{\text {imdzppo }} \rightarrow \pi_{\text {tfmpiq }}^{*}$ & 0.0308 & 576 & 464 \\
\hline & $\mathrm{S}_{2}$ & HOMO-1 $\rightarrow$ LUMO (94 \%) & MLCT/LC & $\mathrm{d} \pi_{\mathrm{Ir}} / \pi_{\mathrm{tfmpiq}} \rightarrow \pi_{\text {tfmpiq }}$ & 0.0401 & 501 & \\
\hline $2 \mathbf{b}$ & $\mathrm{S}_{1}$ & HOMO $\rightarrow$ LUMO (91\%) & MLCT/LLCT & $\mathrm{d} \pi_{\mathrm{Ir}} / \pi_{\mathrm{idzpo}} \rightarrow \pi_{\text {tfmpiq }}^{*}$ & 0.0641 & 526 & 477 \\
\hline
\end{tabular}

Table 6. Contribution of triplet transitions and transition characters for complexes $\mathbf{2 a - 2 b}$.

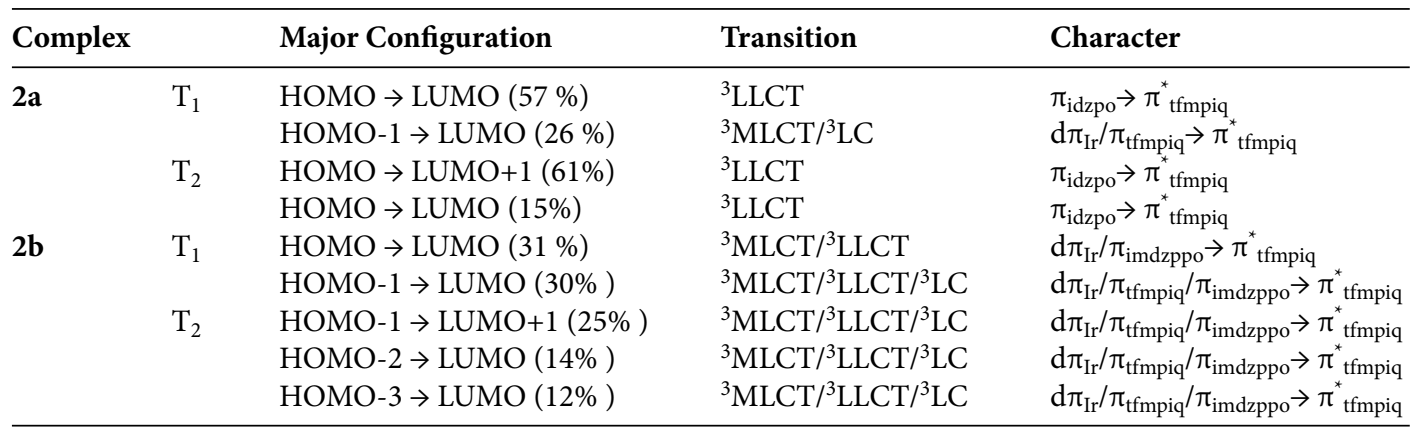




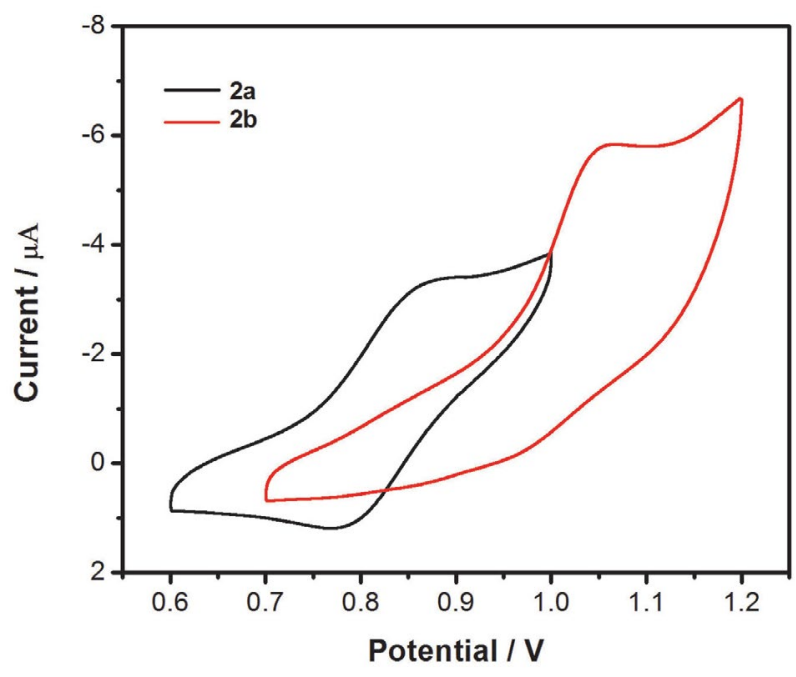

Fig. 5. Cyclic voltammograms for complexes $\mathbf{2 a - 2 b}$ in $\mathrm{CH}_{2} \mathrm{Cl}_{2}$ solution containing $n-\mathrm{Bu}_{4} \mathrm{NClO}_{4}(0.1 \mathrm{M})$ at a sweep rate of $100 \mathrm{mV} / \mathrm{s}$.

quasi-reversible/irreversible oxidation peak $\left(E_{o x}\right)$ at 0.87 and $1.05 \mathrm{~V}$, respectively. As inferred from DFT calculations (Table S1), the HOMOs are mainly localized on the Ir ion $(13.88 \%$ for $\mathbf{2 a}, 24.74 \%$ for $\mathbf{2 b})$ and ancillary ligands (75.74 \% for $\mathbf{2 a}, 58.06 \%$ for $\mathbf{2 b}$ ). Therefore, the oxidation is assigned to $\operatorname{Ir}(\mathrm{III})$ to $\operatorname{Ir}(\mathrm{IV})$ with some contribution from ancillary ligand. On the basis of the potentials of the oxidation, the $\mathrm{HOMO}$ energy is deduced by the equation $E_{\mathrm{HOMO}}$ $=-\left(E_{\mathrm{ox}}+4.8 \mathrm{eV}\right),{ }^{44}$ and the trend is quite consistent with theoretical calculation values (Table 4 ). As it can be seen from these results, through changes of nitrogen atoms from 2,8-positions to 1,2-positions, the HOMO level of $\mathbf{2 b}$ is more stable and the oxidation process is more difficult than those of analogue $\mathbf{2 a}$.

\section{Conclusions}

In conclusion, two red-emitting iridium(III) complexes (2a-2b) equipped with tfmpiq cyclometalated ligand and imdzppo/idzpo ancillary ligand, have been successfully synthesized and characterized. Their photophysical properties, electrochemical behaviors and theoretical calculations have been systematically studied. The calculated absorptions of the two complexes $\mathbf{2 a - 2 b}$ are in full agreement with the experimental data, which indicate that the lowest lying absorptions are assigned to MLCT/LLCT transitions. Both Ir(III) complexes exhibit red phosphorescence in dichloromethane solution at $298 \mathrm{~K}$ and at $77 \mathrm{~K}$, and the lowest lying triplet excited states have a mixed ${ }^{3} \mathrm{MLCT} /{ }^{3} \mathrm{LLCT} /{ }^{3} \mathrm{LC}$ character. By changing the positions of $\mathrm{N}$ atoms in the ancillary ligand, we have confirmed complex $\mathbf{2 b}$ had a further red-shift relative to $\mathbf{2} \mathbf{a}$ in the emission spectra. These research results will facilitate the design of new piq-based ligands for red-emitting iridium complexes.

\section{Acknowledgments}

This work was supported by the Natural Science Foundation of Hainan Province (218QN236, 219MS043, 217115), the 2018 National Innovation Experiment Program for University Students and Program for Innovative Research Team in University (IRT-16R19).

\section{References}

1. Y. S. Li, J. L. Liao, K. T. Lin, W. Y. Hung, S. H. Liu, G. H. Lee, P. T. Chou, Y. Chi, Inorg. Chem. 2017, 56, 10054-10060. DOI:10.1021/acs.inorgchem.7b01583

2. R. D. Costa, E. Orti, H. J. Bolink, F. Monti, G. Accorsi, N. Armaroli, Angew. Chem. Int. Ed. 2012, 51, 8178-8211. DOI:10.1002/anie.201201471

3. B. W. D’Andrade, S. R. Forrest, Adv. Mater. 2004, 16, 1585-1595. DOI:10.1002/adma.200400684

4. C. H. Fan, P. Sun, T. H. Su, C. H. Cheng, Adv. Mater. 2011, 23, 2981-2985. DOI:10.1002/adma.201100610

5. C. H. Chen, L. C. Hsu, P. Rajamalli, Y. W. Chang, F. I. Wu, C. Y. Liao, M. J. Chiu, P. Y. Chou, M. J. Huang, L. K. Chu, C. H. Cheng, J. Mater. Chem. C 2014, 2, 6183-6191. DOI:10.1039/C4TC00523F

6. J. Qiao, L. Duan, L. T. Tang, L. He, L. D. Wang, Y. Qiu, J. Mater. Chem. 2009, 19, 6573-6580. DOI:10.1039/b906675f

7. S. C. Lo, E. B. Namdas, P. L. Burn, I. D. W. Samuel, Macromolecules 2003, 36, 9721-9730. DOI:10.1021/ma030383w

8. C. T. Chen, Chem. Mater. 2004, 16, 4389-4400. DOI: $10.1021 / \mathrm{cm} 049679 \mathrm{~m}$

9. A. Tsuboyama, H. Iwawaki, M. Furugori, T. Mukaide, J. Kamatani, S. Igawa, T. Moriyama, S. Miura, T. Takiguchi, S. Okada, M. Hoshino, K. Ueno, J. Am. Chem. Soc. 2003, 125, 12971-12979. DOI:10.1021/ja034732d

10. Y. J. Su, H. L. Huang, C. L. Li, C. H. Chien, Y. T. Tao, P. T. Chou, S. Datta, R. S. Liu, Adv. Mater. 2003, 15, 884-888. DOI:10.1002/adma.200304630

11. C. L. Li, Y. J. Su, Y. T. Tao, P. T. Chou, C. H. Chien, C. C. Cheng, R. S. Liu, Adv. Funct. Mater. 2005, 15, 387-395. DOI:10.1002/adfm.200305100

12. S. Huo, J. C. Deaton, M. Rajeswaran, W. C. Lenhart, Inorg. Chem. 2006, 45, 3155-3157. DOI:10.1021/ic060089v

13. G. N. Li, S. B. Dou, T. Zheng, X. Q. Chen, X. H. Yang, S. Wang, W. Sun, G. Y. Chen, Z. R. Mo, Z. G. Niu, Organometallics 2018, 37, 78-86. DOI:10.1021/acs.organomet.7b00740

14. F. Babudri, G. M. Farinola, F. Naso, R. Ragni, Chem. Commun. 2007, 0, 1003-1022. DOI:10.1039/B611336B

15. K. H. Fang, L. L. Wu, Y. T. Huang, C. H. Yang, I. W. Sun, Inorg. Chim. Acta 2006, 359, 441-450.

DOI:10.1016/j.ica.2005.10.003

16. S. Zhang, L. S. Xue, C. Wu, Y. X. Zheng, J. L. Zuo, Chin. J. Inorg. Chem. 2014, 30, 134-141.

DOI: 10.11862/CJIC.2014.073

17. Z. G. Niu, D. Liu, J. Zuo, Y. Zou, J. M. Yang, Y. H. Su, Y. D. Yang, G. N. Li, Inorg. Chem. Commun. 2014, 43, 146-150. DOI:10.1016/j.inoche.2014.02.031 
18. Y. Tamura, Y. Hisamatsu, S. Kumar, T. Itoh, K. Sato, R. Kuroda, S. Aoki, Inorg. Chem. 2017, 56, 812-833.

DOI:10.1021/acs.inorgchem.6b02270

19. G. N. Li, Y. Zou, Y. D. Yang, J. Liang, F. Cui, T. Zheng, H. Xie, Z. G. Niu, J. Fluoresc. 2014, 24, 1545-1552.

DOI:10.1007/s10895-014-1443-7

20. H. H. Rhoa, Y. H. Parkb, Y. H. Leeb, N. G. Parkc, Y. Had, Y. S. Kimd, Mol. Cryst. Liq. Cryst. 2006, 444, 145-155.

DOI:10.1080/15421400500365326

21. A. J. Stasyuk, M. Banasiewicz, M. K. Cyrański, D. T. Gryko, J. Org. Chem. 2012, 77, 5552-5558. DOI:10.1021/jo300643w

22. T. V. Nykaza, T. S. Harrison, A. Ghosh, R. A. Putnik, A. T. Radosevich, J. Am. Chem. Soc. 2017, 139, 6839-6842. DOI:10.1021/jacs.7b03260

23. CrysAlisPro Version 1.171.36.21; Agilent Technologies Inc., Santa Clara, CA, USA, 2012.

24. G. M. Sheldrick, Acta Cryst. A 2008, 64, 112-122. DOI:10.1107/S0108767307043930

25. O. V. Dolomanov, L. J. Bourhis, R. J. Gildea, J. A. K. Howard, H. Puschmann, J. Appl. Cryst. 2009, 42, 339-341.

DOI:10.1107/S0021889808042726

26. M. J. Frisch, G. W. Trucks, H. B. Schlegel, G. E. Scuseria, M. A. Robb, J. R. Cheeseman, J. A. Montgomery, T. Vreven, K. N. Kudin, J. C. Burant, J. M. Millam, S. S. Iyengar, J. Tomasi, V. Barone, B. Mennucci, M. Cossi, G. Scalmani, N. Rega, G. A. Petersson, H. Nakatsuji, M. Hada, M. Ehara, K. Toyota, R. Fukuda, J. Hasegawa, M. Ishida, T. Nakajima, Y. Honda, O. Kitao, H. Nakai, M. Klene, X. Li, J. E. Knox, H. P. Hratchian, J. B. Cross, C. Adamo, J. Jaramillo, R. Gomperts, R. E. Stratmann, O. Yazyev, A. J. Austin, R. Cammi, C. Pomelli, J. W. Ochterski, P. Y. Ayala, K. Morokuma, G. A. Voth, P. Salvador, J. J. Dannenberg, V. G. Zakrzewski, S. Dapprich, A. D. Daniels, M. C. Strain, O. Farkas, D. K. Malick, A. D. Rabuck, K. Raghavachari, J. B. Foresman, J. V. Ortiz, Q. Cui, A. G. Baboul, S. Clifford, J. Cioslowski, B. B. Stefanov, G. Liu, A. Liashenko, P. Piskorz, I. Komaromi, R. L. Martin, D. J. Fox, T. Keith, M. A. Al-Laham, C. Y. Peng, A. Nanayakkara, M. Challacombe, P. M. W. Gill, B. Johnson, W. Chen, M. W. Wong, C. Gonzalez, J. A. Pople, Gaussian 09, Revision A.01, Gaussian, Inc. Wallingford, CT, 2009.

27. C. Lee, W. Yang, R. G. Parr, Phys. Rev. B 1988, 37, 785-789. DOI:10.1103/PhysRevB.37.785

28. B. Miehlich, A. Savin, H. Stoll, H. Preuss, Chem. Phys. Lett. 1989, 157, 200-206. DOI:10.1016/0009-2614(89)87234-3
29. A. D. Becke, J. Chem. Phys. 1993, 98, 5648-5652. DOI:10.1063/1.464913

30. M. Cossi, N. Rega, G. Scalmani, V. Barone, J. Comput. Chem. 2003, 24, 669-681. DOI:10.1002/jcc.10189

31. J. Tomasi, B. Mennucci, R. Cammi, Chem. Rev. 2005, 105, 2999-3093. DOI:10.1021/cr9904009 9

32. S. Lamansky, P. Djurovich, D. Murphy, F. Abdel-Razzaq, R. Kwong, I. Tsyba, M. Bortz, B. Mui, R. Bau, Inorg. Chem. 2001, 40, 1704-1711. DOI:10.1021/ic0008969

33. A. B. Tamayo, B. D. Alleyne, P. I. Djurovich, S. Lamansky, I. Tsyba, N. N. Ho, R. Bau, M. E. Thompson, J. Am. Chem. Soc. 2003, 125, 7377-7387. DOI:10.1021/ja034537z

34. K. K. W. Lo, C. K. Chung, N. Y. Zhu, Chem. Eur. J. 2003, 9, 475-483. DOI:10.1002/chem.200390050

35. S. Lamansky, P. Djurovich, D. Murphy, F. Abdel-Razzaq, R. Kwong, I. Tsyba, M. Bortz, B. Mmui, R. Bau, M. E. Thompson, Inorg. Chem. 2001, 40, 1704-1711. DOI:10.1021/ic0008969

36. C. H. Yang, J. Beltran, V. Lemaur, J. Cornil, D. Hartmann, W. Sarfert, R. Fröhlich, C. Bizzarri, C. L. De, Inorg. Chem. 2010, 49, 9891-9901. DOI:10.1021/ic1009253

37. F. Monti, F. Kessler, M. Delgado, J. Frey, F. Bazzanini, G. Accorsi, N. Armaroli, H. J. Bolink, E. Ortí, R. Scopelliti, M. K. Nazeeruddin, E. Baranoff, Inorg. Chem. 2013, 52, 10292-10305. DOI:10.1021/ic400600d

38. T. Y. Li, X. Liang, L. Zhou, C. Wu, S. Zhang, X. Liu, G. Z. Lu, L. S. Xue, Y. X. Zheng, J. L. Zuo, Inorg. Chem. 2015, 54, 161-173. DOI:10.1021/ic501949h

39. S. Okada, K. Okinaka, H. Iwawaki, M. Furugori, M. Hashimoto, T. Mukaide, J. Kamatani, S. Igawa, A. Tsuboyama, T. Takiguchi, K. Ueno, Dalton Trans. 2005, 9, 1583-1590. DOI:10.1039/b417058j

40. Z. G. Niu, T. Zheng, Y. H. Su, P. J. Wang, X. Y. Li, F. Cui, J. Liang, G. N. Li, New J. Chem. 2015, 39, 6025-6033. DOI:10.1039/C5NJ00975H

41. K. A. King, P. J. Spellane, R. J. Watts, J. Am. Chem. Soc. 1985, 107, 1431-1432. DOI:10.1021/ja00291a064

42. C. L. Ho, W. Y. Wong, Q. Wang, D. Ma, L. Wang, Z. Lin, Adv. Funct. Mater. 2008, 18, 928-937.

DOI:10.1002/adfm.200701115

43. Y. Wang, N. Herron, V. V. Grushin, D. LeCloux, V. Petrov, Appl. Phys. Lett. 2001, 79, 449. DOI:10.1063/1.1384903

44. W. Lee, T. H. Kwon, J. Kwon, J. Y. Kim, C. Lee, J. I. Hong, New J. Chem. 2011, 35, 2557-2563. DOI:10.1039/c1nj20446g 


\section{Povzetek}

Sintetizirali smo dva nova bis-ciklometalirana iridijeva(III) kompleksa s tfmpiq ligandom, [(tfmpiq) 2 Ir(imdzppo)] (2a) in $\left[(\mathrm{tfmpiq})_{2} \operatorname{Ir}(\mathrm{idzpo})\right](\mathbf{2 b})(\mathrm{tfmpiq}=1$-(4-(trifluorometil)fenil)izokinolin, imdzppo = 2-(imidazo[1,2-a]piridin-2-il) fenol, idzpo = 2-(2H-indazol-2-il)fenol), in ju okarakterizirali. Določili smo monokristalno strukturo 2b. Določili smo razmerje med strukturo in fotofizikalnimi lastnostmi obeh kompleksov podprto tudi z DFT izračuni. Ir(III) kompleksa emitirata rdečo svetlobo s kvantnim izkoristkom 39.9-51.9 \% v degaziranem $\mathrm{CH}_{2} \mathrm{Cl}_{2}$ pri sobni temperaturi. Emisija izvira iz hibridnega ${ }^{3} \mathrm{MLCT} /{ }^{3} \mathrm{LLCT} /{ }^{3} \mathrm{LC}$ vzbujenega stanja. Vsi ti rezultati kažejo, da sta iridijeva(III) kompleksa 2a-2b primerna kot rdeča fosforescentna materiala v OLED. 